\title{
PENTINGNYA PERAN PERAWAT DALAM PENERAPAN KESELAMATAN PASIEN DI RUMAH SAKIT
}

\author{
Muhaini Atmayana Purba / 181101131 \\ muhainipurba21@gmail.com
}

\begin{abstract}
ABSTRAK
Latar belakang : Penerapan keselamatan pasien merupakan sesuatu yang jauh lebih penting dengan kemampuan perawat dalam penerapan keselamatan pasien sangat berperan penting di dalamnya. Tujuan : Tujuan penulisan ini yaitu mengidenifikasi pentingnya peran perawat dalam penerapan keselamatan pasien di rumah sakit. Metode : Metode yang digunakan merupakan literatur review atau suatu perbandingan atau analisis antara satu jurnal dengan jurnal lainnya dari berbagai sumber seperti referensi jurnal, buku teks dan e-book. Hasil : Hasil dari analisis ini menyatakan bahwa dalam menerapkan keselamatan pasien di rumah sakit, peran perawat sangatlah penting di dalam melaksanakannya. Kesimpulan : Dalam meningkatkan keselamatan pasien perawat berperan penting demi berlangsungnya keselamatan pasien di rumah sakit.
\end{abstract}

Kata Kunci : Peran perawat, penerapan keselamatan pasien, rumah sakit

\begin{abstract}
Background : The application of patient safety is something far more important with the ability of nurses in the application of patient safety is very important role in it. Purpose : The purpose of this paper is to identify the important role of nurses in the application of patient safety in hospitals. Method : The method used is a literature review or a comparison or analysis of one journal with other journals from various sources such as journal references, textbooks and ebooks. Results : The results of this analysis state that in implementing patient safety in hospitals, the role of nurses is very important in implementing them. Conclusion : In improving patient safety nurses play an important role for the survival of patients in the hospital.
\end{abstract}

Keywords : Role of nurses, application of patient safety, hospital. 


\section{Latar Belakang}

Isu keselamatan pasien merupakan salah satu isu utama dalam pelayanan kesehatan. Patient safety merupakan sesuatu yang jauh lebih penting daripada sekedar efisiensi pelayanan. Berbagai resiko akibat tindakan medik dapat terjadi sebagai bagian dari pelayanan kepada pasien (Pinzon 2008).

World Health Organization (WHO) pada tahun 2004 mengumpulkan angka - angka penelitian rumah sakit di berbagai Negara : Amerika, Inggris, Denmark, dan Australia, ditemukan KTD dengan rentang 3.2 - 16,6\%. Data - data tersebut menjadikan pemicu berbagai negara segera melakukan penelitian dan mengembangkan sistem keselamatan pasien (DepKes, 2008). Data di Indonesia tentang KTD apalagi Kejadian Nyaris Cedera (Near Miss) masih langka, namum dilain pihak terjadi peningkatan tuduhan "mal praktek", yang belum tentu sesuai dengan pembuktian akhir. Insidensi pelanggaran patient Safety $28.3 \%$ dilakukan oleh perawat. Perawat harus menyadari perannya sehingga harus dapat berpartisipasi aktif dalam mewujudkan patient safety. Kerja keras perawat tidak dapat mencapai level optimal jika tidak didukung dengan sarana prasarana, manajemen rumah sakit dan tenaga kesehatan lainnya (Adib, 2009).

Penelitian serupa tentang hubungan pengetahuan dan motivasi dengan sikap mendukung penerapan program patient safety di Rumah Sakit Umum Daerah Moewardi Surakarta, oleh Aryani (2008) menyimpulkan bahwa pengetahuan perawat pelaksana tentang konsep patient safety baik dan sikap mendukung penerapan program patient safety tinggi. Survey awal yang dilakukan peneliti di Rumah Sakit Liun Kendage Tahuna, memiliki khusus tenaga keperawatan ada 114 orang diperoleh hasil $75 \%$ perawat di instalasi rawat inap RSUD Liun Kendage 41,5\% sudah pernah mengikuti program patient safety dan $58 \%$ belum pernah ikut. Secara keseluruhan program patient Safety sudah di terapkan, namun masalah dilapangan merujuk pada konsep patient safety, karena walaupun sudah pernah mengikuti sosialisasi, tetapi masih ada resiko pasien cedera, resiko jatuh, resiko salah pengobatan, pendelegasian yang tidak akurat saat operan pasien yang mengakibatkan 
keselamatan pasien menjadi kurang maksimal.

\section{Tujuan}

Tujuan penulisan ini yaitu mengidenifikasi pentingnya peran perawat dalam penerapan keselamatan pasien di rumah sakit.

\section{Metode}

Metode yang digunakan merupakan literatur review atau suatu perbandingan atau analisis antara satu jurnal dengan jurnal lainnya dari berbagai sumber seperti referensi jurnal, buku teks dan e-book.

\section{Hasil \& Pembahasan}

\section{Analisa Univariat}

Berdasarkan umur responden, paling banyak berada pada kelompok umur 23 - 27 tahun yakni 55,4\%, kemudian disusul kelompok umur 28 33 yakni 35,4\%, kelompok umur $34-$ 37 tahun yakni 7,7\% dan yang paling sedikit berada pada kelompok umur 43 - 47 tahun yakni 1,5\%.

Berdasarkan wawancara dengan kepala keperawatan Rumah Sakit, untuk 6 tahun terakhir dilakukan penerimaan perawat muda dengan jumlah yang banyak sehingga di setiap ruangan banyak didominasi oleh perawatperawat muda. Hasil penelitian ini sesuai dengan keadaan sebenarnya, yaitu $60 \%$ perawat pelaksana berusia pada rentang produktif karena berkisar 20 - 40 tahun (Shawky, 2010).

Hasil penelitian ini, paling banyak berjenis kelamin perempuan sebesar 95,4\%, sedangkan laki - laki sebesar $4,6 \%$. Berdasarkan survei secara keseluruhan perawat di Rumah Sakit Liun Kendage didominasi oleh perawat perempuan yang tersebar di seluruh ruangan rawat inap maupun rawat jalan. Hasil penelitian ini memiliki kesamaan dengan teori yang dikemukakan bahwa jenis kelamin perawat didominasi oleh perempuan, karena dalam sejarahnya keperawatan muncul sebagai peran care taking (pemberi perawatan) secara tradisional di dalam keluarga dan masyarakat (Rolinson dan Kish, 2010). Berdasarkan hasil penelitian ini, tingkat pendidikan dari responden paling banyak memiliki pendidikan DIII sebanyak $87,7 \%$ dan yang paling sedikit S1 Ns sebanyak 1,5\%. Ini dipengaruhi oleh tempat perguruan tinggi yang ada di Daerah Sangihe hanya ada lulusan DIII keperawatan. Perawat dengan pendidikan DIII ini tersebar di seluruh ruangan di Rumah Sakit sedangkan perawat dengan lulusan S1 dan S1 Ns masih berjumlah sedikit. Hasil penelitian ini sesuai dengan penelitian 
sebelumnya yang menyatakan lebih dari $60 \%$ perawat masih berpendidikan DIII di Indonesia (Soeroso, 2003).

Berdasarkan hasil penelitian, paling banyak responden tidak pernah mengikuti pelatihan yang berhubungan dengan keselamatan pasien (patient safety) yakni sebanyak 58,5\% dan yang pernah mengikuti pelatihan sebanyak 41,5\%. Di Rumah Sakit Liun Kendage belum pernah diadakan pelatihan yang berhubungan dengan patient safety. Namun perawat-perawat yang telah mengikuti pelatihan yang berhubungan dengan patient safety, mengikuti pelatihan di luar Daerah Sangihe dimana paling banyak berasal dari Kota Manado. Sebagian besar perawat perawat yang ada di seluruh ruangan telah mengikuti pelatihan walaupun jumlah perawat yang belum pernah mengikuti pelatihan yang berhubungan dengan patient safety lebih banyak. Perawat pelaksana yang pernah mendapat pelatihan dan belum mendapat pelatihan tidak memiliki perbedaan dalam pelaksanaan keselamatan pasien. Hal ini didukung penelitian sebelumnya yang menyatakan bahwa tidak terdapat perbedaan bermakna tentang pelatihan perawat pelaksana dengan budaya kerja (Marpaung, 2005).

\section{Analisa Bivariat}

Gambaran pengetahuan perawat tentang keselamatan pasien di setiap ruangan sudah baik ini ditunjukkan oleh hasil penelitian dimana menunjukkan pengetahuan setiap responden telah baik dengan jumlah keseluruhan yakni 90,8\%. Pengetahuan merupakan faktor penting dalam seseorang mengambil keputusan namun tidak selamanya pengetahuan seseorang bisa menghindarkan dirinya dari kejadian yang tidak diinginkannya, misalnya perawat yang tingkat pengetahuannya baik tidak selamanya melaksanakan keselamatan pasien dengan baik karean segala tindakan yang akan dilakukan beresiko untuk terjadi kesalahan.

Berdasarkan observasi yang dilakukan oleh peneliti, diketahui bahwa gambaran di atas di pengaruhi oleh kepatuhan perawat tentang Standar Operasional Prosedur (SOP) yang telah diberikan, peran kepemimpinan (kepala perawat Rumah Sakit) yang terus memantau dan mengevaluasi tindakan yang dilakukan setiap perawat pelaksana, dan komunikasi yang baik kepala ruangan dengan perawat 
pelaksana juga antar perawat pelaksana di seluruh ruang rawat inap. Sehingga dari hasil yang diperoleh dapat disimpulkan semakin tinggi pengetahuan seseorang semakin baik dalam pelaksanaan keselamatan pasien (patient safety). Pengetahuan merupakan hasil "tahu" dan ini terjadi setelah seseorang melakukan penginderaan terhadap suatu objek tertentu. Pengetahuan ini merupakan hal yang dominan yang sangat penting untuk terbentuknya tindakan seseorang, dari pengalaman beberapa penelitian ternyata tindakan yang tidak didasari pengetahuan yang baik, tidak akan menghasilkan hasil yang baik (Notoadmojo, 2007). Diperoleh 95\% perawat di rumah sakit mempunyai sikap baik terhadap pelaksanaan keselamatan pasien (patient safety) di rumah sakit. Sikap responden mengenai keselamatan pasien di setiap ruangan sudah baik ini di dasarkan oleh hasil penelitian yakni 92,3\%. Sedangkan sikap responden dengan pelaksanaan keselamatan pasien di ruang rawat inap paling banyak sudah baik yakni 95,0\% sedangkan sikap responden dengan pelaksanaan keselamatan pasien kurang yakni 5,0\%. Berdasarkan observasi peneliti, gambaran ini dipengaruhi oleh kepatuhan dan tanggung jawab setiap perawat pelaksana terhadap keselamatan pasien itu sendiri. Sikap dikatakan sebagai fungsi dari manusia seperti persepsi, motivasi dan berpikir yang seperti itu menunjukan hubunganhubungan, bahwa sampai batasbatas tertentu perilakunya dapat diramalkan (Mar'at, 2006). Sikap yang baik dapat terwujud jika didasarkan pada tanggung jawab atas segala sesuatu yang telah dipilihnya dengan segala resiko yang merupakan sikap yang paling tinggi (Rumbewas, 2009). Suatu sikap belum tentu otomatis terwujud dalam suatu tindakan (overt behavior). Untuk mewujudkan sikap menjadi suatu perbuatan nyata diperlukan faktor pendukung atau suatu kondisi yang memungkinkan antara lain adalah fasilitas (Notoatmojo, 2003).

\section{Kesimpulan \& Saran}

Berdasarkan hasil penelitian tentang hubungan pengetahuan dan sikap perawat dengan pelaksanaan keselamatan pasien (patient safety) di ruang rawat inap RSUD Liun Kendage Tahuna dapat disimpulkan sebagai berikut: Ada hubungan pengetahuan perawat dengan pelaksanaan keselamatan pasien (patient safety) di Ruang Rawat Inap RSUD Liun 
Kendage Tahuna, dimana 95\% perawat pelaksana mempunyai pengetahuan baik tentang pelaksanaan keselamatan pasien, dan ada hubungan sikap perawat dengan pelaksanaan keselamatan pasien (patient safety) di Ruang Rawat Inap RSUD Liun Kendage Tahuna, dimana 95\% perawat pelaksana mempunyai sikap yang baik dalam melaksanakan keselamatan pasien.

\section{Daftar Pustaka}

Bawelle, (2013). Jurnal Hubungan Pengetahuan dan Sikap Perawat dengan Pelaksanaan Keselamatan Pasien (Patient Safety) di Ruang Rawat Inap RSUD Liun Kandage Tahuna. Program Studi Ilmu Keperawatan Fakultas Kedokteran Universitas Sam Ratulangi, ejournal keperawatan (e-Kp), Manado.

Cahyono, Suharjo. (2008) Membangun

Budaya Keselamatan Pasien dalam Praktik Kedokteran. Yogyakarta : Kanisius

Dewi,Mursidah. (2012). Pengaruh Pelatihan Timbang Terima Pasien Terhadap Penerapan Keselamatan Pasien Oleh Perawat Pelaksana Di RSUD Raden Mattaher Jambi.Jurnal Health \& Suport.5,(3):647:652.
Iskandar, Heru, Halimi Maksum, dan Nafisah. (2014). Faktor Penyebab Penurunan Pelaporan Insiden Keselamatan Pasien Rumah Sakit. Malang : Fakultas Kedokteran Universitas Brawijaya Malang, 2014 Nugroho, SriH.P., Sujianto,U. Supervisi Kepala Ruang Model Proctor Untuk Meningkatkan Pelaksanaan Keselamatan Pasien. Jurnal Keperawatan Indonesia.20, (1):56-64

Notoatmodjo, S. (2003). Pendidikan dan Perilaku Kesehatan. Jakarta : PT. Rineka Cipta.

Potter \& Perry, (2005). Buku Ajar Fundamental Keperawatan : Konsep, Proses, dan Praktik. Edisi 4. Jakarta : EGC.

Rahayu, Sri. (2011). Pengembangan Program Patient Safety Berdasarkan Awareness dan Komitmen Individu. RSUD Ibnu Sina Kabupaten Gresik

Rachmawati, Alifa Rizqia, dkk. (2017). ANALISIS PELAKSANAAN TUJUH LANGKAH MENUJU KESELAMATAN PASIEN DI RUMAH SAKIT ISLAM SULTAN AGUNG SEMARANG. JURNAL 
KESEHATAN MASYARAKAT

(e-Journal) Volume 5, Nomor 1

(ISSN: 2356-3346)

R.H, Simamora. (2019). Buku Ajar

Pelaksanaan Identifikasi Pasien.

Uwais Inspirasi Indonesia

R.H, Simamora. (2019). Documentation

Of Patient Identification Into The

Electronic System To Improve

The Quality Of Nursing Services.

International Jurnal Of Sciensific

\& Technology

R.H, Simamora. (2019). The Influence Of Training Handover Based SBAR Communication For Improving Patients Safety. Indian Journal Of Public Health Research \& Deveropment.

Utami, Yuni Wulan \& Supratman. (2009). HUBUNGAN ANTARA PENGETAHUAN DENGAN SIKAP PERAWAT DALAM PEMENUHAN KEBUTUHAN SPIRITUAL PASIEN DI BRSUD SUKOHARJO. Berita Ilmu Keperawatan ISSN 1979-2697, Vol. 2 No. 2 : 69-74

Widajat, Rochmanadji. (2009). Being a Great and Sustainable Hospital. Jakarta : PT Gramedia Pustaka Utama
Yusuf, Muhammad. (2017). Penerapan Patient Safety Di Ruang Rawat Inap Rumah Sakit Umum Daerah Dr.Zainoel Abidin.Jurnal Ilmu Keperawatan. 5,(1):85-88. 